\title{
Photomosaics and Logs of Trenches Associated with Study of West Napa Fault at Ehlers Lane, North of Saint Helena, California
}

By Belle E. Philibosian, Robert R. Sickler, Carol S. Prentice, Alexandra J. Pickering, Patrick Gannon,

Kiara N. Broudy, Shannon A. Mahan, Jazmine N. Titular, Eli A. Turner, Cameron Folmar, Sierra F. Patterson, and Emilie E. Bowman

Pamphlet to accompany

Open-File Report 2022-1002 


\section{U.S. Geological Survey, Reston, Virginia: 2022}

For more information on the USGS — the Federal source for science about the Earth, its natural and living resources, natural hazards, and the environment-visit https://www.usgs.gov or call 1-888-ASK-USGS.

For an overview of USGS information products, including maps, imagery, and publications, visit https://store.usgs.gov.

Any use of trade, firm, or product names is for descriptive purposes only and does not imply endorsement by the U.S. Government.

Although this information product, for the most part, is in the public domain, it also may contain copyrighted materials as noted in the text. Permission to reproduce copyrighted items must be secured from the copyright owner.

Suggested citation:

Philibosian, B.E., Sickler, R.R., Prentice, C.S., Pickering, A.J., Gannon, P., Broudy, K.N., Mahan, S.A., Titular, J.N., Turner, E.A., Folmar, C., Patterson, S.F., and Bowman, E.E., 2022, Photomosaics and logs associated with study of West Napa Fault at Ehlers Lane, north of Saint Helena, California: U.S. Geological Survey Open-File Report 2022-1002, 1 sheet, pamphlet 8 p., https://doi.org/10.3133/ofr20221002.

ISSN 2331-1258 (online 


\section{Acknowledgments}

The National Association of Geoscience Teachers USGS internship program supported seven intern coauthors (P. Gannon, K.N. Broudy, J.N. Titular, E.A. Turner, C. Folmar, S.F. Patterson, and E.E. Bowman) who assisted with field work, sample collection, data processing, drafting, and data synthesis. Belle Philibosian was supported by a Mendenhall Postdoctoral Fellowship. We thank Chris DuRoss, Suzanne Hecker, and Steve DeLong for providing thorough manuscript reviews that led to many improvements. Thanks also to David Schwartz and Steve DeLong for providing trench reviews and logistical support. We are very grateful to Battuello Vineyards and neighboring landowners for allowing this study on their properties and providing background information about the history and local geology of their land. 


\section{Contents}

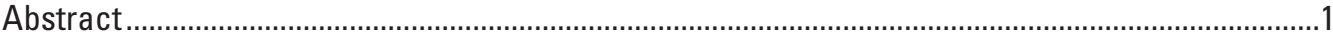

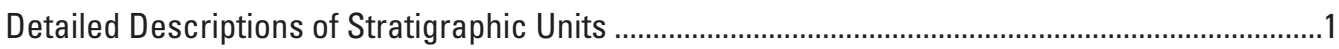

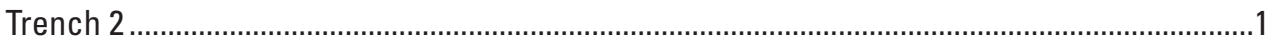

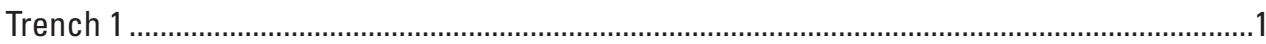

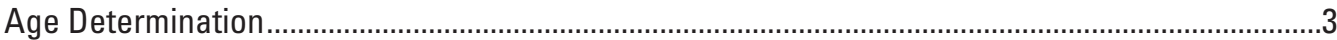

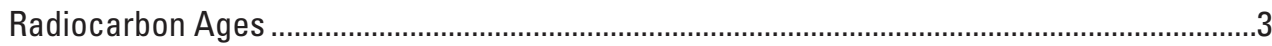

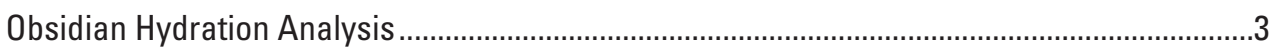

Infrared-Stimulated Luminescence .....................................................................................

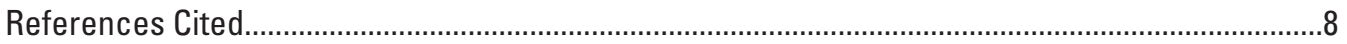

\section{Tables}

1. Descriptions of stratigraphic units and position of unconformities on the west end of trench 2

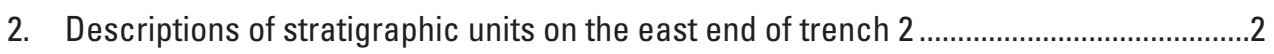

3. Descriptions of stratigraphic units on the west end of trench 1 .......................................

4. Descriptions of stratigraphic units and position of unconformities in the middle of trench 1..............................................................................................................

5. Descriptions of stratigraphic units and position of unconformities on the east end of trench 1 .

6. Radiocarbon analysis results for Ehlers Lane site samples, Saint Helena, California .....5

7. Obsidian hydration analysis results for Ehlers Lane site samples, Saint Helena, California

8. Feldspar infrared-stimulated luminescence analysis results for Ehlers Lane site samples, Saint Helena, California. 


\title{
Photomosaics and Logs of Trenches Associated with Study of West Napa Fault at Ehlers Lane, North of Saint Helena, California
}

\author{
By Belle E. Philibosian, ${ }^{1}$ Robert R. Sickler, ${ }^{1}$ Carol S. Prentice, ${ }^{1}$ Alexandra J. Pickering, ${ }^{1}$ Patrick Gannon, ${ }^{1,2}$ \\ Kiara N. Broudy, ${ }^{1,3}$ Shannon A. Mahan, ${ }^{1}$ Jazmine N. Titular, ${ }^{1,4}$ Eli A. Turner, ${ }^{1}$ Cameron Folmar, ${ }^{1}$ Sierra F. Patterson, ${ }^{1}$ \\ and Emilie E. Bowman ${ }^{1,5}$
}

\section{Abstract}

The West Napa Fault has previously been mapped as extending $\sim 45$ kilometers $(\mathrm{km})$ from northern Vallejo to southern Saint Helena, California, dominantly running along the western edge of Napa Valley. A zone of fault strands (some previously unmapped) along a $\sim 15-\mathrm{km}$ section of the fault ruptured during the 2014 magnitude 6.0 South Napa earthquake, illustrating the need for further investigation of this little-studied structure. Based on light detection and ranging (lidar) topography and field examination, the fault zone likely extends an additional $10 \mathrm{~km}$ or more northward past Saint Helena. In this vicinity, geomorphology suggests two fault strands, one along the range front and another associated with a line of rounded hills that rise 5-10 meters above the middle of the valley. In 2017, we excavated two trenches across an apparent fault scarp on the east side of one elongate hill near Ehlers Lane north of Saint Helena. Examination of the walls revealed three main sedimentary packages. The oldest package, weakly lithified alluvial fan gravels with local sand and silt layers, is tilted $25^{\circ}-35^{\circ}$ to the west. Overlying these tilted strata are two younger sets of strata. On the west side, underlying the crest of the scarp, are alluvial fan gravels with local sand and silt lenses, potentially tilted a few degrees to the west. On the east side, deposited against the scarp, are much finer grained (dominantly fine sand to silt) subhorizontal fluvial strata, likely overbank deposits from the Napa River. We obtained age control on the two younger units through a combination of radiocarbon, infrared-stimulated luminescence, and obsidian hydration dating, establishing that they are latest Pleistocene to modern in age. Although there are no prominent unconformities within the alluvial fan sediments, sample dating indicates there

\footnotetext{
${ }^{1}$ U.S. Geological Survey.

${ }^{2}$ Now at EA Engineering, Science, and Technology, Inc., PBC.

${ }^{3}$ Now at Langan Engineering and Environmental Services, Inc.

${ }^{4}$ Now at Wood Rodgers, Inc.

${ }^{5}$ Now at University of Arizona.
}

are two generations, one in the 10-20 thousand year (ka) age range and one in the $<3 \mathrm{ka}$ age range. Owing to a general lack of well-defined laterally continuous alluvial fan units, it is difficult to distinguish contacts between the two generations except in the immediate proximity of dated samples. The river sediments approximately span the Holocene. No faults were apparent in either trench, indicating that any fault related to the observed surface deformation has not ruptured to the surface at this site during the Holocene and is likely blind.

\section{Detailed Descriptions of Stratigraphic Units}

\section{Trench 2}

The northern trench (2) revealed distal river sediments deposited against colluvium-mantled tilted strata at the western end. At the western end of the trench, the river sediments are only coarsely stratified (five discernible units). These sediments are more finely stratified toward the east, differentiating into more than 15 discernible units (with additional underlying layers revealed in a deepened part of the trench). Therefore, we present separate unit descriptions for the west and east ends in the following two tables (tables 1 and 2).

\section{Trench 1}

The southern trench (1) revealed a buried ridge of tilted strata, overlain by alluvial fan sediments on its west flank and distal river sediments on its east flank. Individual units within the alluvial fan sediments have limited lateral continuity and most do not directly contact the river sediments, so it is difficult to determine stratigraphic relations between all units. Therefore, we present separate unit descriptions for the west end, middle, and east end of the trench in three tables (tables 3, 4, and 5, respectively). 
Table 1. Descriptions of stratigraphic units and position of unconformities on the west end of trench 2.

\begin{tabular}{|c|c|}
\hline Unit symbol & Description or feature \\
\hline 1 & Tilled light gray silty soil with rounded pebbles and cobbles, abundant roots, loose and blocky with large soil peds \\
\hline$\alpha$ & $\begin{array}{l}\text { Black-gray clay-rich soil. Upper part is harder, lighter colored, more clay- and silt-rich with more granules and pebbles. Lower part is loose with } \\
\text { small soil peds, organic rich, and more friable. Transitions into unit } 2 \text { to east }\end{array}$ \\
\hline$\beta$ & $\begin{array}{l}\text { Unsorted black-gray, organic-rich silt-sand soil with scattered pebbles and cobbles. Siltier and harder in places, sandier and looser in others. } \\
\text { Contains a light gray zone. Likely tilled to } 1 \text { meter depth. Cobbles reworked from the unit below are common along base. Differentiates into } \\
\text { units 3-8 to east }\end{array}$ \\
\hline$\gamma$ & $\begin{array}{l}\text { Dry, hard, light gray medium-coarse sandy silt to silty sand with many pebbles and a few cobbles. Coarser on average than units } \beta \text { and } \delta \text {. Largely } \\
\text { matrix supported, intermittently clast supported. Differentiates into units } 9-10.5 \text { to east }\end{array}$ \\
\hline$\delta$ & $\begin{array}{l}\text { Dry, hard, grayish light-brown fine sand and silt with abundant granules and small pebbles. Contains a diffuse coarse layer (coarse sand to pebbly } \\
\text { silt with cobbles). Differentiates into units } 11-13 \text { to east }\end{array}$ \\
\hline- & Buttress unconformity \\
\hline Col & $\begin{array}{l}\text { Colluvium mantle likely derived from underlying layers below angular unconformity. Unsorted loose gray small-medium cobbles and scattered } \\
\text { boulders in silty matrix, generally matrix supported; subrounded to rounded clasts generally inclined to the east }\end{array}$ \\
\hline- & Angular unconformity \\
\hline BAU1 & Oxidized, hard, light gray clayey silt \\
\hline BAU2 & $\begin{array}{l}\text { Oxidized, yellow rounded cobbles and boulders. More cemented than overlying unit. Mainly clast supported. Matrix, where present, is oxidized } \\
\text { coarse silty sand. Consistent inclination of cobbles and contacts suggests } \sim 25^{\circ} \text { westward dip }\end{array}$ \\
\hline BAU3 & Well-rounded granules and some small pebbles; larger pebbles near base \\
\hline BAU4 & Medium to coarse sand \\
\hline BAU5 & Silt to fine sand with some granules and small pebbles \\
\hline
\end{tabular}

Table 2. Descriptions of stratigraphic units on the east end of trench 2.

\begin{tabular}{|c|c|}
\hline Unit symbol & Description \\
\hline 1 & Tilled light gray silty soil with rounded pebbles and cobbles. Abundant roots present. Soil is loose and blocky with large soil peds \\
\hline 2 & $\begin{array}{l}\text { Pale orange breccia, possibly artificial fill for railroad grade. Color transitions to less yellow and more gray to the west. Locally contains tilled } \\
\text { blocks of unit } 3\end{array}$ \\
\hline 3 & Dark gray-brown massive silt with pebbles and granules \\
\hline 4 & Layer or stringer of rounded cobbles; intermittent \\
\hline $4 \mathrm{a}$ & Brown pebbly silt \\
\hline 5 & Coarse sand and granule gravel with yellow and white subangular pebbles. Dark brown silty clay matrix \\
\hline 6 & Medium-dark brown silty clay with lenses and scattered clasts of coarser material including white granules, very coarse sand, and pebbles \\
\hline 7 & Dominantly white tuff clast-supported granule layer \\
\hline 8 & Greenish medium-brown massive silty clay with lenses of coarser material; fewer scattered granules and very coarse sand grains than in unit 6 \\
\hline 9 & White, gray, and brown clast-supported very coarse sand and white tuff granules with local clay lenses and some iron staining \\
\hline 10 & Greenish medium-brown silty clay with few pebbles and granules. Locally layered. Contains charcoal- rich burn horizon at meters $20-22$ \\
\hline 10.5 & White, gray, and red pebbles and scattered cobbles in clay to fine sand matrix; subangular clasts. Fines and pinches out to east \\
\hline 11 & Medium brown generally massive silty clay with very abundant pebbles and granules; dry with desiccation cracks \\
\hline 12 & Medium-dark brown massive silty clay with scattered granules and pebbles; dry and hard with abundant desiccation cracks \\
\hline 13 & $\begin{array}{l}\text { Light brown massive silty clay with abundant white and gray pebbles and granules; increasing pebble and cobble content (entrained colluvium) to } \\
\text { the west. Granule lenses near top in the eastern part. Hard and slightly damp }\end{array}$ \\
\hline 13.5 & Subrounded medium pebbles to cobbles with matrix that ranges from medium brown silt to coarse sand. Coarser matrix than unit 13 \\
\hline 14 & $\begin{array}{l}\text { Orange-brown massive silty clay with scattered white and gray coarse sand grains, granules, and pebbles. Dry, very hard, and cement-like at top, } \\
\text { becomes slightly damp and darkens downward. The lower third of the unit contains more fine sand and pebbles, locally in lenses, and interfin- } \\
\text { gers with unit } 15 \text {. Sand and pebble content increases toward the west }\end{array}$ \\
\hline 15 & $\begin{array}{l}\text { Clast-supported gravel composed of subrounded to well-rounded large pebbles and cobbles in fine sand and silt matrix with granules. Wet and } \\
\text { very friable }\end{array}$ \\
\hline 16 & $\begin{array}{l}\text { Matrix-supported gravel composed of rounded white granules and pebbles in clay-rich matrix; damp and loose. Contains fewer pebbles and cobbles } \\
\text { than the layers above and below; transitions from silty clay matrix with few pebbles to sandy matrix with many pebbles from east to west }\end{array}$ \\
\hline 16.5 & Grayish-blue sandy, silty clay with sparse subrounded cobbles and white pebbles \\
\hline 17 & $\begin{array}{l}\text { Clast-supported gravel composed of subangular to subrounded pebbles and cobbles in sandy granule matrix; wet and loose at top and well- } \\
\text { cemented at base }\end{array}$ \\
\hline
\end{tabular}


Table 3. Descriptions of stratigraphic units on the west end of trench 1.

[cm, centimeter]

\begin{tabular}{|c|c|c|}
\hline $\begin{array}{c}\text { Unit } \\
\text { symbol }\end{array}$ & $\begin{array}{l}\text { Subunit } \\
\text { symbol }\end{array}$ & Description \\
\hline A3 & - & $\begin{array}{l}\text { Blocky soil composed of well-rounded cobbles in organic-rich brown-gray silt; friable with soil peds. Bioturbated base forms a weathering } \\
\text { horizon on units } \mathrm{C} 1 \text { and } \mathrm{C} 2 \text { with relict blocks of } \mathrm{C} 1 \text { and } \mathrm{C} 2 \text { found within unit } \mathrm{A} 3\end{array}$ \\
\hline A4 & - & Yellow well-rounded cobbles in yellow to pale orange cemented matrix with iron staining \\
\hline $\mathrm{C} 1$ & - & $\begin{array}{l}\text { Pale orange, moderately rounded, poorly sorted, cemented, iron-stained cobble gravel; grades in and out of unit C2. Possibly the uppermost } \\
\text { part of unit F with some soil development }\end{array}$ \\
\hline $\mathrm{C} 2$ & - & $\begin{array}{l}\text { Dry, hard, massive pebbly clay, silt, and coarse sand with extensive bioturbation and burrowing. Perhaps simply expresses weak soil devel- } \\
\text { opment in finer parts of unit } \mathrm{C} 1 \text { and (or) top of unit F rather than a distinct stratigraphic unit }\end{array}$ \\
\hline $\mathrm{Ch}$ & - & Granules to small pebbles in sandy silt matrix fill channels incised into unit $\mathrm{F}$; finer and less cemented than unit $\mathrm{F}$ \\
\hline $\mathrm{D}$ & - & Pebbles in silt matrix; matrix supported \\
\hline $\mathrm{E}$ & & Upward-fining pebble gravel to fine sand layers present only at far western end of trench \\
\hline- & E1 & Massive, bioturbated fine sand with few pebbles \\
\hline- & E2 & Clast-supported pebble gravel in west; pebble-rich zone in east \\
\hline- & E3 & Clast-supported pebble gravel composed of moderately rounded clasts in silty very coarse sand matrix; weakly bedded and iron stained \\
\hline $\mathrm{F}$ & - & $\begin{array}{l}\text { Pale orange, poorly sorted, moderately rounded sandy pebble gravel with significant burrowing and iron staining. Maximum clast size of } \sim 10 \mathrm{~cm} \text {. } \\
\text { Contains cemented finer gravel lenses; becomes more cemented and fines (more sand, fewer cobbles, less rounded clasts) to west on average. } \\
\text { Cobble poor and matrix supported at meters } 26-29 \text {. Similar to unit M but more poorly sorted. Roughly grades into units } \mathrm{N} \text { and } \mathrm{O} \text { to east }\end{array}$ \\
\hline G & - & Interfingering sand lenses. Upper lens (unit G1) is medium to very coarse sand with pebbles and lower lens (unit G2) is sorted very fine sand \\
\hline $\mathrm{H}$ & - & Pebble gravel, coarser than unit E3; iron stained \\
\hline I & - & Locally well sorted medium sand with faint and thin coarse sand and pebble interbeds; manganese and iron staining \\
\hline $\mathrm{J}$ & - & Orange-mottled, poorly sorted, subrounded, clast-supported sandy cobble gravel; grades to pebble gravel to west. Loose and iron stained \\
\hline K & - & Pale orange, poorly sorted pebble and cobble gravel in silty sand matrix; maximum clast size of $\sim 7 \mathrm{~cm}$. Hard and well-cemented \\
\hline $\mathrm{L}$ & - & $\begin{array}{l}\text { White-yellow silty fine to coarse sand lenses, the majority of which are massive, well-sorted silty fine sand. Coarse sand, granule, and pebble } \\
\text { interbeds present; some lenses exhibit faint laminae and (or) iron staining. Units L1-L4 indicate distinct lenses that dip to either side from } \\
\text { center of unit; this may be depositional dip. Interfingers with units J, K, and M }\end{array}$ \\
\hline M & - & $\begin{array}{l}\text { Gray clast-supported gravel composed of subangular to subrounded pebbles in a coarse sand and granule matrix, friable to weakly cemented. } \\
\text { Locally sorted; finer (pebbles in sand) to west, loose clast-supported gravel lenses with void space and very little matrix in east. Manga- } \\
\text { nese staining in east }\end{array}$ \\
\hline
\end{tabular}

\section{Age Determination}

Three different methods were used to estimate ages of strata: radiocarbon dating, obsidian hydration dating, and luminescence dating. Of these three, radiocarbon dating provides the most precise ages, but can only be performed on samples of organic matter. Organic material (largely charcoal) is plentiful within the river deposits but scarce in the other units. We dated a representative suite of radiocarbon samples from throughout the section of river sediments and every available sample from the other units. Obsidian hydration dating is less precise but is much less expensive than radiocarbon dating. We supplemented the radiocarbon ages by dating every available obsidian sample. However, like organic material, obsidian is plentiful in the river deposits but scarce elsewhere. For the alluvial fan deposits, we rely on luminescence dating, which is the least precise method but can be performed on any finegrained sediment. We also obtained a series of luminescence dates from the river deposits to verify that ages are consistent among the three methods.

\section{Radiocarbon Ages}

The radiocarbon dating method measures the ratio of the radioactive isotope of carbon $\left({ }^{14} \mathrm{C}\right)$ to the stable isotopes ${ }^{13} \mathrm{C}$ and ${ }^{12} \mathrm{C}$ in a sample of dead organic matter. This determines the time elapsed since the sample of living tissue died. This age of death may therefore be significantly older than the age of deposition of the unit in which the sample is found, particularly if the samples are charcoal, which can have a long period of surface residence and transport before final deposition. All samples of organic matter found in the Ehlers Lane trenches are charcoal (table 6).

\section{Obsidian Hydration Analysis}

Over time, the outer surface of an obsidian clast reacts with water in the environment to form a hydrate rind or band. The band thickness increases with time, so the age of the clast surface can be determined from the band thickness (measured using microscopy) and a known band growth rate. The latter 
Table 4. Descriptions of stratigraphic units and position of unconformities in the middle of trench 1.

[mm, millimeter]

\begin{tabular}{|c|c|}
\hline Unit symbol & Description \\
\hline A1 & Modern soil A horizon; unsorted silt and sand with some pebbles and cobbles \\
\hline A2 & Unsorted silt to coarse sand with few pebbles and cobbles \\
\hline A3 & Blocky soil composed of well-rounded cobbles in organic-rich brown-gray silt; friable with soil peds \\
\hline $\mathrm{N}$ & $\begin{array}{l}\text { In-place remnants of well-cemented gravel composed of unsorted silt, sand, pebbles, and few cobbles, surrounded by bioturbation and burrows } \\
\text { Finer than and interfingering with or below unit F }\end{array}$ \\
\hline $\mathrm{O}$ & Pebbly unsorted silty sand with few cobbles; extensive bioturbation and burrowing \\
\hline $\mathrm{P}$ & $\begin{array}{l}\text { Dry, very hard, cemented, poorly sorted, massive pebble and cobble gravel with coarse sand and granule matrix; fines upward to pebbly } \\
\text { medium-coarse sand on south wall. Appears to grade into unit } U \text { to the east }\end{array}$ \\
\hline Q & Pebbly coarse sand \\
\hline $\mathrm{R}$ & $\begin{array}{l}\text { Dry pebble gravel with matrix of silty very coarse sand and granules. Contains medium-coarse sand lenses and cobble layer along base. Crude } \\
\text { bedding and manganese staining }\end{array}$ \\
\hline $\mathrm{S}$ & Pebble to cobble gravel, similar to and grades into unit $\mathrm{K}$ to west \\
\hline $\mathrm{T}$ & Gray pebble gravel, finer than unit $\mathrm{S}$, similar to and possibly grades into unit $\mathrm{M}$ to west \\
\hline- & Angular unconformity \\
\hline BAU10 & Massive pebble and cobble gravel; finer layer at top \\
\hline BAU11 & Layered coarse sand, small pebble gravel, and medium sand fill channel incised into unit BAU12 \\
\hline BAU12 & $\begin{array}{l}\text { Interbedded distinct layers of silt, silty medium sand, coarse sand, and granule to pebble gravel with crossbedding and laminae. Clear westwarc } \\
\text { dip of } \sim 30^{\circ}\end{array}$ \\
\hline BAU13 & $\begin{array}{l}\text { Massive pebble and cobble gravel with loose very coarse sand and granule matrix. Mostly clast supported, locally matrix supported; crude } \\
\text { orientation of clasts and indistinct bedding at 1-meter scale suggests westward dip. Iron and manganese staining }\end{array}$ \\
\hline BAU14 & $\begin{array}{l}\text { Yellow-orange mottled massive silty fine sand; fines upward. Dry and hard with in situ burrows, subvertical weathering fabric, and iron stain- } \\
\text { ing. Contains } 3-5 \mathrm{~mm} \text { thick planar gray clay layer }\end{array}$ \\
\hline BAU15 & Clast-supported pebble and cobble gravel exhibiting clast orientation that suggests westward dip \\
\hline
\end{tabular}

Table 5. Descriptions of stratigraphic units and position of unconformities on the east end of trench 1.

[cm, centimeter]

\begin{tabular}{|c|c|c|}
\hline $\begin{array}{c}\text { Unit } \\
\text { symbol }\end{array}$ & $\begin{array}{l}\text { Subunit } \\
\text { symbol }\end{array}$ & Description or feature \\
\hline A1 & - & Modern soil A horizon; organic-rich, loose pebbly sand and silt with soil peds \\
\hline B & - & Massive sandy silt with scattered pebbles; most pebbles are subrounded with weathering rinds \\
\hline- & B1 & Dark brown, organic-rich, dry, hard, massive pebbly sand and silt with abundant roots and desiccation cracks \\
\hline- & B2 & $\begin{array}{l}\text { Ashen gray to light brown massive sandy silt with scattered pebbles as large as } 4 \mathrm{~cm} \text { in diameter. Dry and hard with scattered roots and } \\
\text { some granule lenses; becomes less distinct to west }\end{array}$ \\
\hline- & B3 & Thin lens of gray silt with scattered granules \\
\hline- & B4 & $\begin{array}{l}\text { Gray-mottled medium brown massive sandy silt. Dry and hard with numerous desiccation cracks, many vertical gleyed zones, fewer pock- } \\
\text { ets of granules than unit B2, and many weathered pebbles as large as } 5 \mathrm{~cm} \text { in diameter }\end{array}$ \\
\hline- & B5 & $\begin{array}{l}\text { Orange-mottled to yellow-brown massive clayey silt with scattered pebbles; finer than the rest of unit B. Slightly damp with subvertical } \\
\text { weathering fabric }\end{array}$ \\
\hline $\mathrm{U}$ & - & $\begin{array}{l}\text { Cobble colluvium mantle likely derived from underlying layers below angular unconformity. Largely clast supported; becomes finer and } \\
\text { supported in brown matrix to east. Interfingers with base of unit B4 and unit B5 to east }\end{array}$ \\
\hline $\mathrm{V}$ & - & $\begin{array}{l}\text { Orange-tinged pebbly sand-silt colluvium, likely derived from unit BAU14. Transitions from clast supported to matrix supported from bot- } \\
\text { tom to top. Interfingers with unit B5 to east }\end{array}$ \\
\hline- & - & Angular unconformity \\
\hline
\end{tabular}


depends on obsidian composition and burial environment and has been empirically calibrated for Napa Valley's Glass Mountain obsidian using samples of independently known age (for example, Carpenter and Mikkelsen, 2005). Using X-ray diffraction analysis, all obsidian samples collected at the Ehlers Lane site were determined to be consistent with a Napa Valley Glass Mountain source (unsurprising as Glass Mountain is only a few kilometers from the Ehlers Lane site). As with radiocarbon samples, the age of the clast could be substantially older than the age of deposition. The surface ages on obsidian debitage (humanworked flakes) are likely closer to the age of deposition than the surface ages on naturally eroded clasts. Obsidian hydration ages for the Ehlers Lane site are given in table 7.

\section{Infrared-Stimulated Luminescence}

Buried sediments trap electrons that are emitted by decay of local radioactive elements. Light exposure releases these trapped electrons within seconds to minutes. Luminescence dating works by measuring the stored luminescence in mineral grains of quartz or potassium feldspar under controlled conditions in the laboratory, then taking that result divided by the isotopic decay of known radioactive minerals that generate the luminescence. Visible light is used on quartz grains whereas infrared wavelengths are used on feldspar grains. Our samples had very little quartz, so we used infrared-stimulated luminescence dating on the feldspars (table 8).

Table 6. Radiocarbon analysis results for Ehlers Lane site samples, Saint Helena, California.

[USGS, U.S. Geological Survey; \%o, per mil; NIST, National Institute of Standards and Technology; SRM, standard reference material; $\mu$ g, microgram]

\begin{tabular}{|c|c|c|c|c|c|c|c|}
\hline Sample & USGS no. ${ }^{1}$ & Material & Pretreatment $^{2}$ & $\mathbf{F}^{14} \mathbf{C} \pm 2 \sigma^{3}$ & ${ }^{14} \mathrm{C}$ age $\pm 2 \sigma^{4}$ & Trench & $\begin{array}{c}\text { Stratigraphic } \\
\text { unit }^{5}\end{array}$ \\
\hline Nm-10C-a-ch & 1299 & Charcoal & $\mathrm{ABA}$ & $0.6806 \pm 0.0036$ & $3,090 \pm 40$ & 2 & 6 \\
\hline Sm-16D-a-ch & 1300 & Charcoal & $\mathrm{ABA}$ & $0.6940 \pm 0.0038$ & $2,935 \pm 40$ & 2 & 9 \\
\hline Sm33D-a-ch & 1301 & Charcoal & $\mathrm{ABA}$ & $0.6941 \pm 0.0038$ & $2,935 \pm 40$ & 2 & $\delta$ top $(\approx 11)$ \\
\hline Sm9E-a-ch & $1302^{6}$ & Charcoal & $\mathrm{ABA}$ & $0.6219 \pm 0.0036$ & $3,815 \pm 50$ & 2 & 12 \\
\hline Sm15G-a-ch & 1303 & Charcoal & $\mathrm{ABA}$ & $0.3719 \pm 0.0030$ & $7,945 \pm 70$ & 2 & 14 top \\
\hline Sm17K-a-ch & 1304 & Charcoal & $\mathrm{ABA}$ & $0.3077 \pm 0.0036$ & $9,470 \pm 90$ & 2 & 14 base \\
\hline Sm11J-b-ch & 1305 & Charcoal & $\mathrm{ABA}$ & $0.3180 \pm 0.0026$ & $9,205 \pm 70$ & 2 & 14 base \\
\hline Nm9J-a-ch & $1342^{6}$ & Charcoal & $\mathrm{ABA}$ & $0.3323 \pm 0.0036$ & $8,850 \pm 90$ & 2 & $15-16$ \\
\hline Sm10J-a-ch & 1341 & Charcoal & $\mathrm{ABA}$ & $0.2659 \pm 0.0032$ & $10,640 \pm 100$ & 2 & 16 \\
\hline S-G7-b-ch & 1297 & Charcoal & $\mathrm{ABA}$ & $0.9295 \pm 0.0050$ & $585 \pm 40$ & 1 east & B1 (in situ) \\
\hline S-G7-a-ch & 1296 & Charcoal & $\mathrm{ABA}$ & $0.9157 \pm 0.0046$ & $705 \pm 40$ & 1 east & $\mathrm{B} 1$ \\
\hline S-H1-a-ch & 1294 & Not enough carbon for analysis & & & & 1 east & B2 \\
\hline S-I3-a-ch & 1295 & Not enough carbon for analysis & & & & 1 east & B4 top \\
\hline S-L0-a-ch & $1293^{6}$ & Charcoal & $\mathrm{ABA}$ & $0.3347 \pm 0.0032$ & $8,790 \pm 80$ & 1 east & B4 base \\
\hline N-L4-a-ch & 1292 & Not enough carbon for analysis & & & & 1 east & B5 \\
\hline N-C29-a-ch & 1289 & Charcoal & $\mathrm{ABA}$ & $0.0066 \pm 0.0022$ & $40,300 \pm 2,800$ & 1 west & C2 (fossil fuel?) \\
\hline $\mathrm{N}-\mathrm{C} 25-\mathrm{b}-\mathrm{ch}$ & 1290 & Charcoal & $\mathrm{ABA}$ & $0.9509 \pm 0.0050$ & $405 \pm 40$ & 1 west & $\mathrm{C} 2$ base \\
\hline S-E28-b-ch & 1298 & Not enough carbon for analysis & & & & 1 west & L1 \\
\hline N-G23-a-ch & 1291 & Not enough carbon for analysis & & & & 1 west & M top \\
\hline
\end{tabular}

${ }^{1}$ Unique identifier for each radiocarbon analysis in the USGS Radiocarbon Laboratory. Analyses were performed by Jeff Pigati and Jeff Honke. Reporting follows standards established by Stuiver and Polach (1977) and van der Plicht and Hogg (2006).

${ }^{2}$ Chemical pretreatment protocol applied to the sample. ABA, acid-base-acid; HCl, hydrochloric acid leach.

${ }^{3}$ Activity ratio of ${ }^{14} \mathrm{C}$ corrected for isotopic fractionation and normalized to a $\delta^{13} \mathrm{C}$ value of $-25 \%$. By convention, the modern reference standard is defined as 95 percent of the ${ }^{14} \mathrm{C}$ activity of NIST Oxalic Acid I (SRM 4990C). Uncertainty is given at the $2 \sigma$ level.

${ }^{4}$ Conventional (uncalibrated) radiocarbon age, based on the Libby half-life of 5,568 years, where 0 years before present is 1950 A.D. Uncertainty is given at the $2 \sigma$ level.

${ }^{5}$ Samples are listed in stratigraphic order within each of the stratigraphic sections (trench 2, trench 1 east, trench 1 west).

${ }^{6}$ Sample yielded $<300 \mu \mathrm{g}$ of carbon. We recommend this result be viewed with caution. 


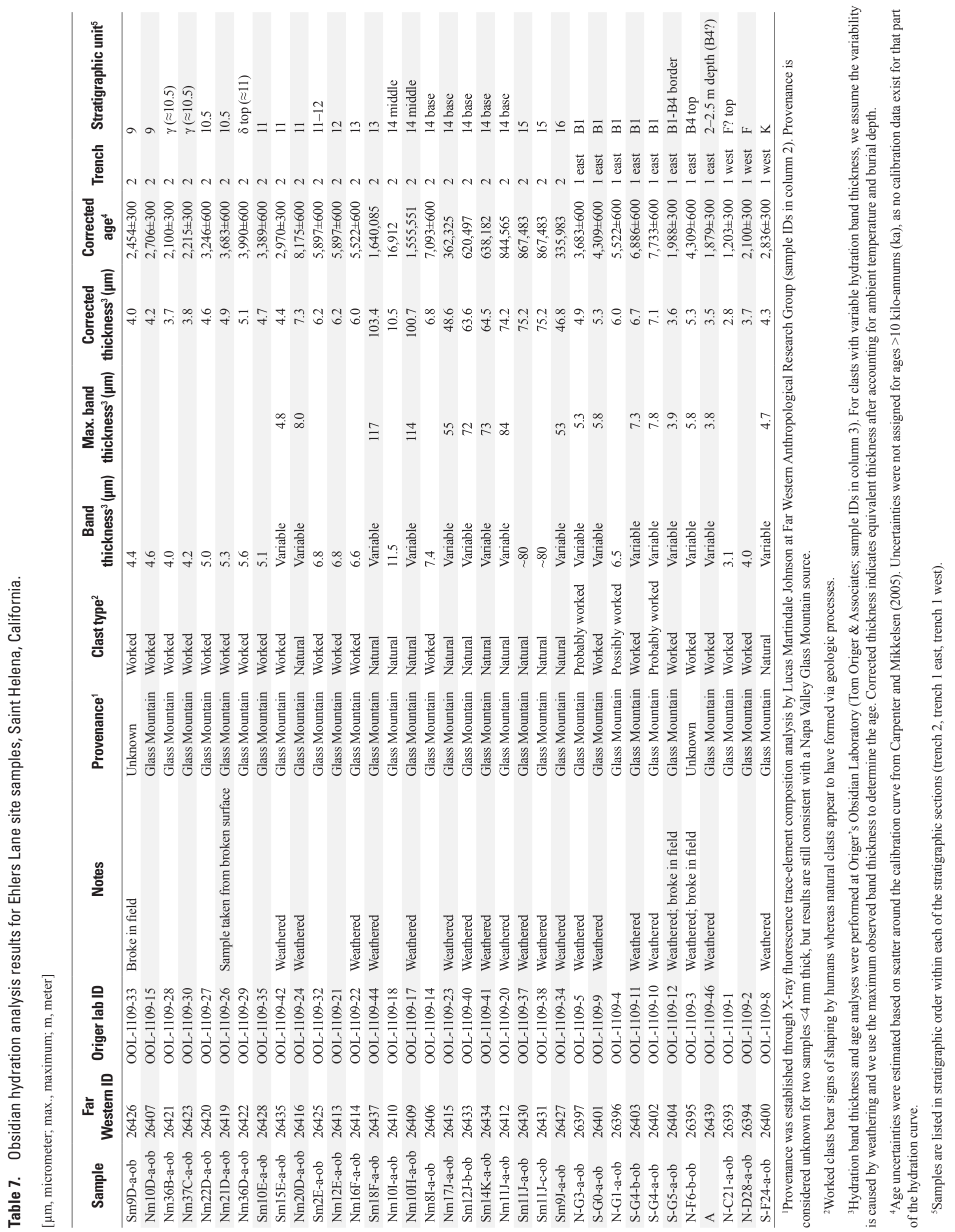




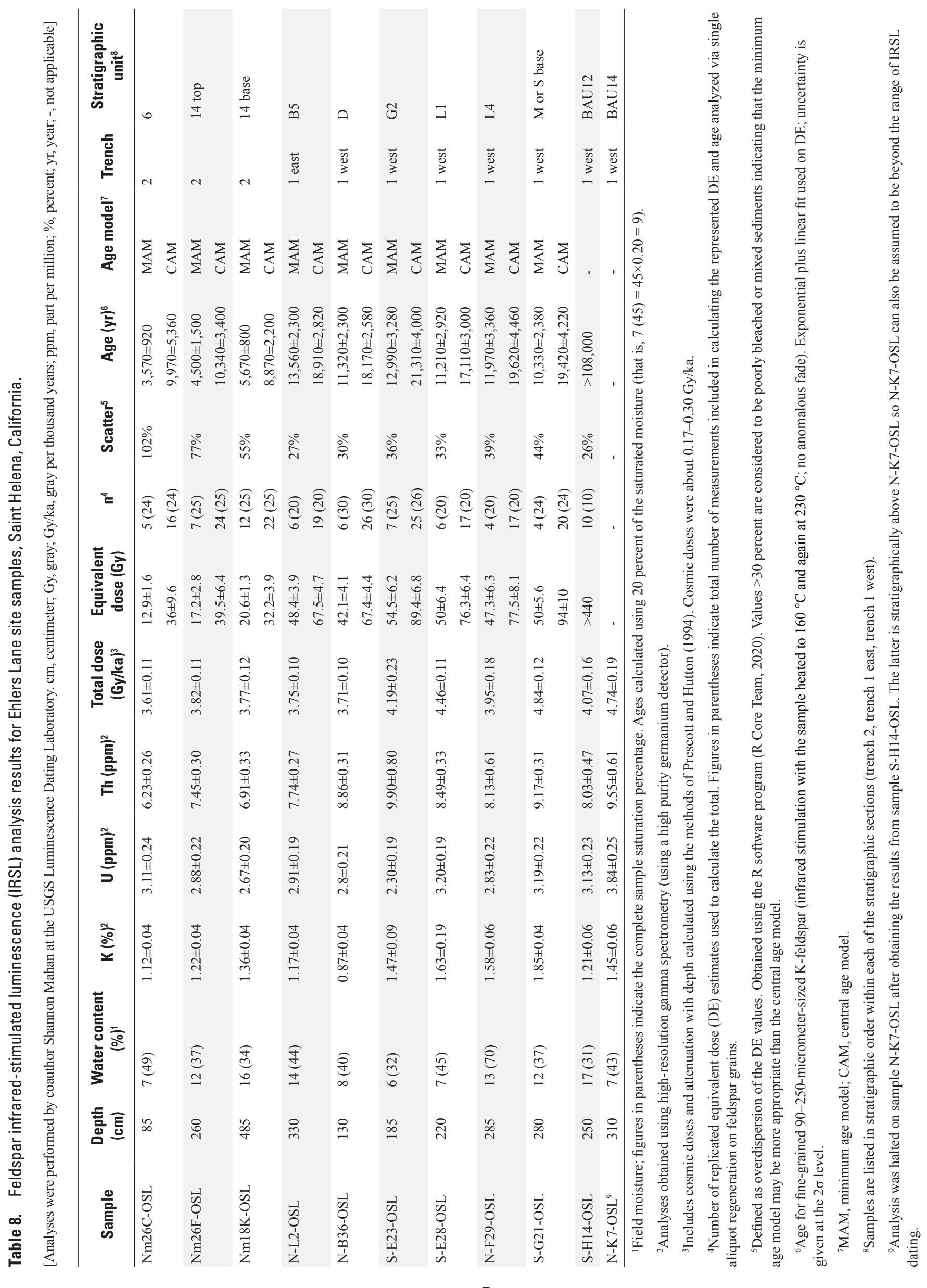




\section{References Cited}

Carpenter, K., and Mikkelsen, P., eds., 2005, Lithic production and craft specialization in the Middle Period-Data recovery excavations at CA-NAP-172: Davis, California, Far Western Anthropological Research Group, Inc. [produced for the City of Calistoga, California], $92 \mathrm{p}$.

National Center for Airborne Laser Mapping [NCALM], 2010, Napa Watershed, CA, airborne lidar [collected in 2003]:

National Center for Airborne Laser Mapping, distributed by OpenTopography, accessed October 1, 2016, at https://doi. org/10.5069/G9BG2KW9.

Pickering, A.J., DeLong, S.B., Philibosian, B.E., and Prentice, C.S., 2021, Lidar point cloud, GNSS, and DEM raster data from the Ehlers Lane fault-study site near St. Helena, California, March 31 and August 1, 2017: U.S. Geological Survey data release, https://doi.org/10.5066/P95MA4XH.

Ponti, D.J., Rosa, C.M., and Blair, J.L., 2019, The Mw 6.0 South Napa earthquake of August 24, 2014 - Observations of surface faulting and ground deformation, with recommendations for improving post-earthquake field investigations: U.S. Geological Survey Open-File Report 2019-1018, 50 p., 15 appendixes, https://doi.org/10.3133/ ofr20191018.

Prescott, J.R., and Hutton, J.T., 1994, Cosmic-ray contributions to dose-rates for luminescence and ESR dating — Large depths and long-term time variations: Radiation Measurements, v. 23, p. 497-500.

R Core Team, 2020, R-A language and environment for statistical computing: Vienna, Austria, R Foundation for Statistical Computing, accessed January 17, 2020, at https:// www.R-project.org.

Stuiver, M., and Polach, H., 1977, Discussion-Reporting of ${ }^{14} \mathrm{C}$ data: Radiocarbon, v. 19 , no. 3, p. 355-363.

U.S. Geological Survey [USGS] and California Geological Survey [CGS], 2019, Quaternary fault and fold database for the United States: U.S. Geological Survey database, accessed June 30, 2019, at https://earthquakes.usgs.gov/hazards/qfaults. van der Plicht, J., and Hogg, A., 2006, A note on reporting radiocarbon: Quaternary Geochronology, v. 1, no. 4, p. 237-240. 